\title{
Ethynylogation approach in antitumor lipid pharmacochemistry: from dialkynyl-carbinols to trialkynyl-carbinols
}

\author{
Maroua Bourkhis, ${ }^{\text {a, b }}$ Dymytrii Listunov, ${ }^{c, d}$ Hafida Gaspard, ${ }^{\text {a Etienne Joly, }}{ }^{\mathrm{e}}$ \\ Raoudha Abderrahim, ${ }^{\mathrm{b}}$ Valérie Maraval, ${ }^{\mathrm{c}, \mathrm{d} *}$ Yves Génisson, ${ }^{\mathrm{a} *}$ Remi Chauvin ${ }^{\mathrm{c}, \mathrm{d} *}$ \\ ${ }^{a}$ UMR CNRS 5068, LSPCMIB, Université de Toulouse, Université Paul Sabatier, 118 Route de \\ Narbonne, 31062 Toulouse cedex 9, France \\ ${ }^{b}$ 05/UR/13-01, LPMLNMH, Université de Carthage, Faculté des sciences de Bizerte, 7021 \\ Jarzouna, Tunisie \\ ${ }^{c}$ CNRS, LCC (Laboratoire de Chimie de Coordination), 205 route de Narbonne, BP 44099, 31077 \\ Toulouse Cedex 4, France \\ ${ }^{d}$ Université de Toulouse, UPS, ICT-FR 2599, 31062 Toulouse Cedex 9, France \\ ${ }^{e}$ UMR CNRS 5089, IPBS (Institut de Pharmacologie et de Biologie Structurale), 205 Route de \\ Narbonne, 31077 Toulouse cedex, France \\ valerie.maraval@1cc-toulouse.fr, genisson@chimie.ups-tlse.fr, chauvin@1cc-toulouse.fr
}

Keywords: alkyne; antitumor agent; ethynylogation; lipid; pharmacophore design; trialkynylcarbinol

\begin{abstract}
A recently proposed "ethynylogation" pharmacomodulation approach, first envisaged in the series of anticancer lipidic dialkynylcarbinols (DACs) $\mathrm{H}-\mathrm{C} \equiv \mathrm{C}-\mathrm{CH}(\mathrm{OH})-\mathrm{C} \equiv \mathrm{C}-\mathrm{R}$ at the levels of the $\mathrm{H}-$ $\mathrm{C}:$ and $: \mathrm{C}-\mathrm{R}$ bonds for $\mathrm{R}=n-\mathrm{C}_{12} \mathrm{H}_{25}$, is completed here at the level of the (HO)C-H bond. The sodevised mono-lipidic trialkynylcarbinol (TAC) target $(\mathrm{HC} \equiv \mathrm{C})_{2} \mathrm{C}(\mathrm{OH})-\mathrm{C} \equiv \mathrm{CR}$ and its bis-lipidic counterpart $\mathrm{HC} \equiv \mathrm{C}-\mathrm{C}(\mathrm{OH})(\mathrm{C} \equiv \mathrm{CR})_{2}$ were synthesized in 4 steps with $33 \%$ and $23 \%$ overall yield, respectively. Their antitumor cytotoxicity has been evaluated towards HCT116 cells: while the latter doubly lipidic TAC is totally inactive $\left(\mathrm{IC}_{50}>120 \mu \mathrm{M}\right)$, the former DAC-ethynylogous TAC still exhibits a significant toxicity with an $\mathrm{IC}_{50}$ of $40 \mu \mathrm{M}$.
\end{abstract}




\section{Introduction}

With the view to setting the title terms in a proper context, scholar emphasis is first given to the basic notion of structure-activity relationships (SARs), which correlate the presence of a generic chemical unit with particular biological/therapeutic effects [1]. The first-key SAR unit can be a global molecular skeleton that can be modified/ decorated by various second-key functional units (e.g. norsteroids, corticosteroids or macrolides, related to contraceptive, anti-inflammatory or antibiotic effects, respectively). On the other hand, the first-key SAR unit can be restricted to a local well-defined substructure, called a pharmacophore [2], that can be embedded in various second-key environments (e.g. betalactams, benzodiazepines or arylpropionic acids related to antimicrobial, anxiolytic or analgesic effects, respectively). It is worth noting that SARs can be more or less specific: the number of identified antitumor pharmacophores is thus actually as large as the number of targetable biochemical pathways, and almost as large as the number of marketed anticancer drugs [3].

Classical optimization approaches around a given pharmacophore consist in sequential modifications of the local environment by isomerization (e.g. enantiomerization), reduction/oxidation (e.g. $\mathrm{CH}-\mathrm{OH} \rightarrow \mathrm{C}=\mathrm{O}$ ), analogation (e. g. $\mathrm{O} \rightarrow \mathrm{S}, \quad \mathrm{CH} \rightarrow \mathrm{N}), \quad \mathrm{C}-\mathrm{H}$ fluorination or general $\mathrm{C}-\mathrm{H}$ substitution. Homologation (by $\mathrm{CH}_{2}$-insertion) and vinylogation (by $-\mathrm{HC}=\mathrm{CH}$ - insertion) are also established pharmacomodulation approaches, within the pharmacophoric unit itself [4] or at its periphery. An alternative "ethynylogation" approach has been recently proposed $[5,6]$ : it is based on the assumption that a third-key SAR criterion would be a distance constraint between the pharmacophore and any component of its surrounding, independently from any relative spatial orientation constraint between them (so regardless conformational effects).

The ethynylogation approach has been first implemented in the series of synthetic lipidic dialkynylcarbinols (DACs) of general formula $\mathrm{HC} \equiv \mathrm{C}-\mathrm{CH}(\mathrm{OH})-\mathrm{C} \equiv \mathrm{CR}$, inspired from natural lipidic alkenyl-alkynylcarbinols (AACs) (E)$\mathrm{HC} \equiv \mathrm{C}-\mathrm{CH}(\mathrm{OH})-\mathrm{CH}=\mathrm{CHR}$ extracted from marine sponges [7]. Beyond efforts aiming at the total synthesis of natural AACs [8], synthesis and biological evaluation of both simplified and modified congeners thereof allowed the identification of non-natural DACs as potent in vitro antitumor cytotoxic agents, in particular against the HCT116 cell-line [9]. Starting from the recently disclosed lead $\mathbf{1}\left(\mathrm{R}=n-\mathrm{C}_{12} \mathrm{H}_{25}, \mathrm{IC}_{50}\right.$ $\approx 0.10 \mu \mathrm{M}$; Figure 1) [5,9a], the $\mathrm{C}_{5} \mathrm{OH}$ DAC unit itself, $\mathrm{C} \equiv \mathrm{C}-\mathrm{C}(\mathrm{OH})-\mathrm{C} \equiv \mathrm{C}$, has been formally separated from either two components of its surrounding, the terminal acetylenic $H$ and the lipidic chain $\mathrm{R}$, by a distance of $c a 2.4 \pm 0.1 \AA$ through the insertion of a $\mathrm{C}_{2}$ ethyndiyl unit. The corresponding independent ethynylogations thus defined the external and internal butadiynyl- 
alkynylcarbinols (BACs) $\mathbf{2}$ and $\mathbf{3}$, respectively, which were synthesized in either racemic or 90 $\%$ ee-scalemic forms [5]. Compared to $\mathbf{1}$, while the external BAC 2 was found to display a decreased cytotoxicity $\left(\mathrm{IC}_{50} \approx 10 \mu \mathrm{M}\right.$ for $\left.r a c-2\right)$, the internal BAC 3 showed an enhancement thereof: $\mathrm{IC}_{50}=0.12 \mu \mathrm{M}$ for $\mathrm{rac}-3$ and $\mathrm{IC}_{50}=$ $0.04 \mu \mathrm{M}$ for $(S)-(+)-3, v s \mathrm{IC}_{50}=0.10 \mu \mathrm{M}$ for $(S)-(+)-1 . \quad$ A dramatic absolute configuration effect, previously observed for the DAC 1 [9a], was thus also evidenced for the BAC $\mathbf{3}$, with an eudismic ratio of $c a$ one order of magnitude.

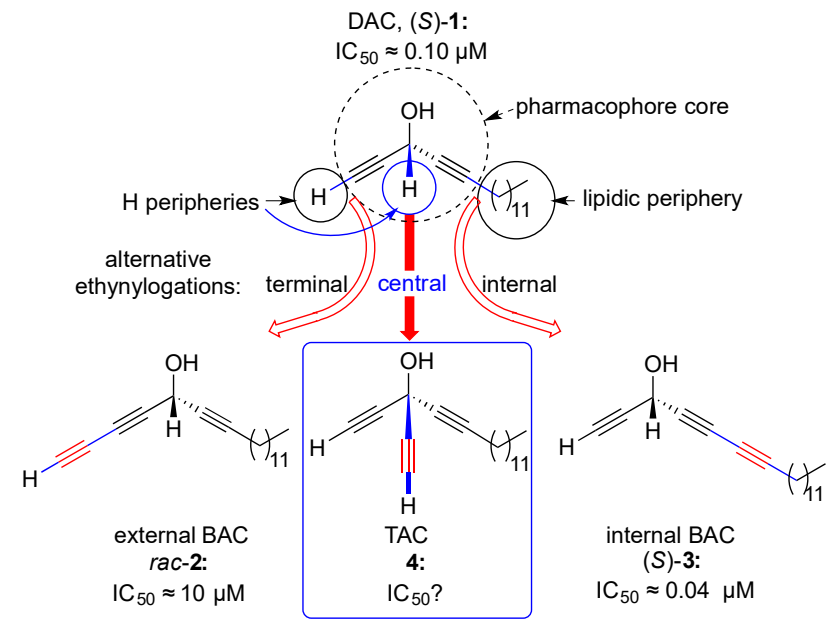

Figure 1. Generalization of the ethynylogation approach in the lipidic DAC series. $\mathrm{IC}_{50}$ values correspond to cytotoxicity against HCT116 tumor cells (MTT tests) [5].

The ethynylogation approach is hereafter implemented for the third surrounding component of the $\mathrm{C}_{5} \mathrm{OH}$ unit, namely the $\mathrm{H}$ atom of the secondary carbinol center of $\mathbf{1}$. The so-devised ethynylogous target is thus the trialkynylcarbinol (TAC) 4. Contrary to the DAC $\mathbf{1}$ and BAC $\mathbf{3}$, the TAC $\mathbf{4}$ is achiral, thus advantageously allowing disregard of asymmetric synthesis issues.

\section{Results and discussion}

The TAC target 4 was prepared in four steps from trimethylsilylacetylene via the previously known DAC 5 and corresponding diynone 6, obtained sequentially with $84 \%$ and $82 \%$ yield, respectively (Scheme 1) [10]. Reaction of 6 with the lithium salt of 1-tetradecyne gave the disilylated TAC 7 with $89 \%$ yield. Ultimate proto-desilylation of 7 to the TAC target 4 in the presence of $\mathrm{K}_{2} \mathrm{CO}_{3}$ in methanol proceeded with a $63 \%$ yield. Both the lipidic TACs 7 and 4 happen to be solid products, which were characterized by ${ }^{1} \mathrm{H},{ }^{13} \mathrm{C}$ NMR spectroscopy and $\mathrm{DCI} / \mathrm{CH}_{4} \mathrm{HRMS}$

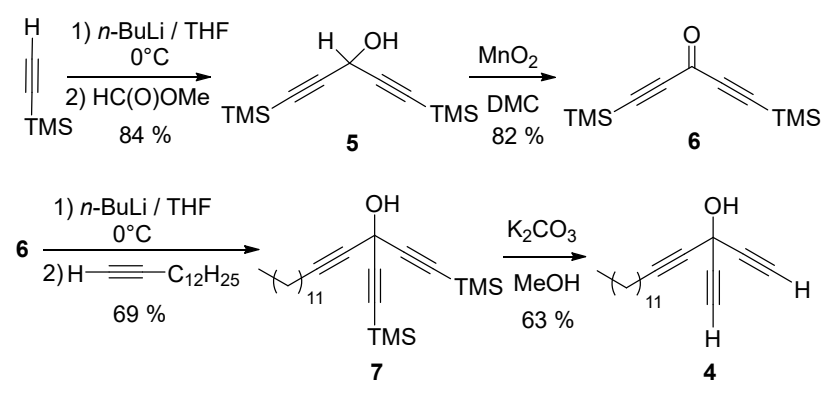

Scheme 1. Four-step synthesis of the mono-lipidic TAC 4.

For the sake of comparison, a TAC bearing a single terminal ethynyl moiety and two lipidic alkynyl chains was also envisaged. The sodefined target 8 was prepared in four steps from 1-tetradecyne, sequentially via the DAC 9 (65 $\%$ yield), the corresponding diynone 10 (70\% yield) and the silylated TAC 11 (64\% yield). Treatment of the latter with $\mathrm{K}_{2} \mathrm{CO}_{3}$ in methanol afforded the TAC 8 with $80 \%$ yield. These previously unknown doubly lipidic "skipped 
diynes" [11] or triynes were obtained as solid products and characterized by ${ }^{1} \mathrm{H},{ }^{13} \mathrm{C}$ NMR spectroscopy and DCI/CH $\mathrm{CH}_{4}$ HRMS.
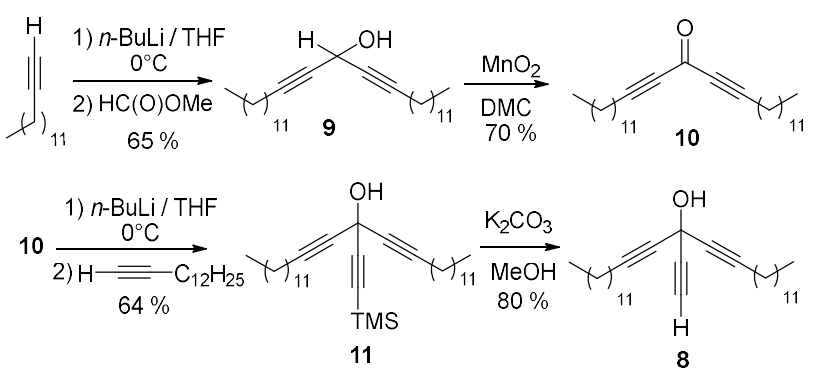

Scheme 2. Four-step synthesis of the bis-lipidic TAC 8.

The cytotoxicity of the TACs $\mathbf{4}$ and $\mathbf{8}$ was evaluated towards the HCT116 cell-line (Table 1), and compared with that of the parent DAC $(S)-(+)-1$ (Table 1). Whereas the doubly lipidic TAC 8 was found to have no detectable activity $\left(\mathrm{IC}_{50}>120 \mu \mathrm{M}\right)$, the mono-lipidic counterpart 4 turned out to display a sizeable cytotoxicity, with $\mathrm{IC}_{50}=40 \mu \mathrm{M}$, namely of the same order of magnitude as the BAC rac-2 (10 $\mu \mathrm{M}$ ) (Figure 1). With the particular batch of HCT116 cells used for the MTT tests, the reference DAC (+)-1 showed a reproducible $\mathrm{IC}_{50}$ value of $0.10 \mu \mathrm{M}$ [5].

In the $\mathrm{HC} \equiv \mathrm{C}-\mathrm{CR}^{\prime}(\mathrm{OH})-\mathrm{C} \equiv \mathrm{CC}_{12} \mathrm{H}_{25}$ tertiary series $\left(\mathbf{R}^{\prime} \neq \mathrm{H}\right)$, the decrease in cytotoxicity of the TACs 4 and $8\left(\mathbf{R}^{\prime}=\mathrm{C} \equiv \mathrm{CH}, \mathrm{C} \equiv \mathrm{CC}_{12} \mathrm{H}_{25}\right)$ with respect to the secondary DAC $\mathbf{1}\left(\mathbf{R}^{\prime}=\mathrm{H}\right)$ is a priori consistent with a previous observation of complete inactivity of the methylated tertiary $\operatorname{DAC}\left(\mathbf{R}^{\prime}=\mathrm{CH}_{3}: \quad \mathrm{IC}_{50}>50 \mu \mathrm{M}\right) \quad[9 \mathrm{~d}]$. Nevertheless, the residual activity of $\mathbf{4}$ shows that the tertiary character of the carbinol center is not a crippling criterion. By comparison to the tertiary methylated DAC [9d] and TAC 8, the sizeable cytotoxicity of $\mathbf{4}$ gives formal support to the ethynylogation approach: from $\mathbf{R}^{\prime}=\mathrm{H}$ in 1 to $\mathbf{R}^{\prime}=\mathrm{C} \equiv \mathrm{CH}$ in 4 , the structure just undergoes a second-order geometrical modification, i.e. a translation of the $\mathrm{H}$ atom from the carbinol center by $2.3 \AA$, resulting in a secondary change of the $\mathrm{IC}_{50}$ value. The same translation of another $\mathrm{H}$ atom of $\mathbf{1}$ (the acetylenic $\mathrm{H}$ ) was observed to have the same effect (in terms of log units) by going from the DAC 1 to the BAC 2 [5].

Table 1. MTT test results against the HCT116 cancer cell-line

\begin{tabular}{ll}
\hline Derivative & $\mathrm{IC}_{50}[\mathrm{nM}]$ \\
\hline$(S)-(+)-\mathbf{1}$ & 0.10 \\
$\mathbf{4}$ & 40 \\
$\mathbf{8}$ & $>120$ \\
\hline
\end{tabular}

The cytotoxicity was evaluated for the lipidic TACs $\mathbf{4}$ and $8 v s$ their parent lipidic DAC 1. Cells were seeded in 96well plates and treated with concentrations ranging from 5 $\mathrm{nM}$ to $120 \mu \mathrm{M}$; after $72 \mathrm{~h}$, the number of live cells was evaluated by standard MTT tests. MTT test of the three compounds were performed in strictly identical conditions (in parallel the same days, with the same biological and auxiliary chemical materials).

The disclosed results are a priori consistent with a basic principle of quantitative SAR (QSAR) analysis, stating that continuous variations of a single structural parameter (here a $\mathrm{C}^{\cdots} \mathrm{H}$ distance, independently from angular parameters and local steric hindrance) entails a "proportional" variation of the biological activity at stake [12]. 


\section{Conclusions and perspectives}

With the view to testing further possible merits of the formal ethynylogation approach, the present results complete the scope of SARs between DACs and anticancer cytotoxicity: beyond the formerly explored BAC series [5], the TAC series is now addressed, providing the first example a tertiary DAC, 4, with a nonvanishing cytotoxicity. Beyond further ethynylogation of the BAC lead $\mathbf{3}$, further prospects are also naturally suggested within the generalized DAC series $\mathrm{H}-\mathrm{C} \equiv \mathrm{C}-\mathrm{CR}^{\prime}(\mathrm{OH})$ $\mathrm{C} \equiv \mathrm{C}-\mathbf{R}$, and in particular the systematic variation of the length of the aliphatic chain $\mathbf{R}$, and the $\mathrm{C}-\mathrm{H}$ fluorination of the carbinol center of $\mathbf{1}$ by going from $\mathbf{R}^{\prime}=\mathbf{H}$ to $\mathbf{R}^{\prime}=\mathbf{F}$. The $\mathrm{F}$ atom should indeed bring less conformational disorder than any alkyl or alkylethynyl $\mathbf{R}^{\prime}$ group, and $c a$. a half iso-directional hindrance compared to the second ethynyl group of $\mathbf{4}\left(\mathbf{R}^{\prime}\right.$ $=\mathrm{C} \equiv \mathrm{CH})$. Beside the limited steric effect, an additional effect of the $\mathrm{F}$ substituent should be the enhancement of the $\mathrm{OH}$ acidic character.

\section{Experimental part}

\section{Synthesis material and methods}

The reactions were carried out under an argon atmosphere, in solvents previously dried and distilled: tetrahydrofuran (THF) over sodium/ benzophenone, dichloromethane (DCM) over $\mathrm{CaH}_{2}$ and methanol (MeOH) over magnesium and iodine. All the other solvents, petroleum ether (PE), ethyl acetate, and reagents were used as commercially available. Commercial solutions of $n$-BuLi were $1.6 \mathrm{M}$ in hexanes. Analytic thin-layer chromatography (TLC) was performed with $0.20 \mathrm{~mm}$ silica gel $60 \mathrm{~F} 254$ plates. Chromatograms were revealed under UV light and/or moistened with $10 \%$ phosphomolybdic acid in EtOH, and visualized on a heating plate. Column chromatography was carried out on silica gel 60A (SDS 35-70 mm). NMR spectra were recorded with a Bruker Avance 300 instrument from solutions of the samples in $\mathrm{CDCl}_{3} .{ }^{1} \mathrm{H}$ and ${ }^{13} \mathrm{C}$ NMR chemical shifts $\delta$ are quoted in parts per million (ppm), with positive values to high frequency relative to the tetramethylsilane reference determined from the residual or main solvent peak; coupling constants $J$ are given in Hertz. Mass spectra (MS) were obtained on a GCT 1er CAB109 (Waters).

\section{Synthesis}

\section{1,5-bis(trimethylsilyl)penta-1,4-diyn-3-ol (5).}

To a flame-dried flask equipped with a condenser, charged with a solution of trimethylsilylacetylene $(0.5 \mathrm{~mL}, 3.61 \mathrm{mmol}, 1$ equiv.) in THF $(20 \mathrm{~mL})$, was dropwise added 1.6 M solution of $n$-BuLi in hexanes $(2.2 \mathrm{~mL}$, $3.43 \mathrm{mmol}, 0.95$ equiv.) at $0^{\circ} \mathrm{C}$. After stirring for $20 \mathrm{~min}$ at $0{ }^{\circ} \mathrm{C}$, methyl formate $(106 \mathrm{~mL}$, 1.73 mmol, 0.48 equiv.) was added, and the resulting solution was gently heated to the limit of reflux with the aid of a hair dryer (until appearance of small bubbles and colour change from yellow to brown). After cooling back to 
room temperature and treatment with saturated aqueous $\mathrm{NH}_{4} \mathrm{Cl}$, the aqueous layer was extracted with $\mathrm{Et}_{2} \mathrm{O}$ and the combined organic layers were washed with brine, dried over $\mathrm{MgSO}_{4}$, and concentrated under reduced pressure. The crude product was purified by silica gel chromatography $\left(\mathrm{PE} / \mathrm{Et}_{2} \mathrm{O}, 7 / 3, R_{\mathrm{f}}=0.7\right)$ to give $369 \mathrm{mg}$ of a solid yellow product assigned to the known DAC 5, with $84 \%$ yield. ${ }^{1} \mathrm{H}$ NMR (300 $\left.\mathrm{MHz}, \mathrm{CDCl}_{3}\right) \delta 5.13(\mathrm{~d}, J=6.6 \mathrm{~Hz}, 1 \mathrm{H}), 2.37$ (s, 1H), $0.22(\mathrm{~s}, 18 \mathrm{H}) ;{ }^{13} \mathrm{C}$ NMR $(75 \mathrm{MHz}$, $\left.\mathrm{CDCl}_{3}\right) \delta(2 \mathrm{C} \equiv \mathrm{C})$ 101.65, (2 $\left.\equiv \mathrm{C}-\mathrm{Si}\right)$ 89.73, (COH) 53.04, (9 C-Si) -0.34 .

\section{1,5-bis(trimethylsilyl)penta-1,4-diyn-3-one (6)}

To a solution of 1,5-bis(trimethylsilyl)penta1,4-diyn-3-ol 5 (310 mg, 1.38 mmol, 1 equiv.) in DCM $(15 \mathrm{~mL})$, was added $\gamma-\mathrm{MnO}_{2}$ in one portion (1.8 g, $0.02 \mathrm{~mol}, 15$ equiv.), and the mixture was stirred for $24 \mathrm{~h}$ at room temperature (completion of the reaction monitored by TLC). The reaction mixture was then filtered through a pad of Celite ${ }^{\circledR}$, and the filtrate was concentrated under reduced pressure. The crude product was purified by silica gel chromatography $\left(\mathrm{PE} / \mathrm{Et}_{2} \mathrm{O}, 90 / 10, R_{\mathrm{f}}=\right.$ $0.7)$ to give an orange solid product assigned to the known diynone 6 with $82 \%$ yield. ${ }^{1} \mathrm{H}$ NMR $\left(300 \mathrm{MHz}, \mathrm{CDCl}_{3}\right) \delta 0.29(\mathrm{~s}, 9 \mathrm{H}) ;{ }^{13} \mathrm{C}$ NMR $(75$ $\left.\mathrm{MHz}, \mathrm{CDCl}_{3}\right) \delta(\mathrm{C}=\mathrm{O}) 160.29,(2 \mathrm{C} \equiv \mathrm{C}) 102.51$, ( $2 \equiv \mathrm{C}-\mathrm{Si})$ 99.41, (9 C-Si) $-0.90,-0.92$; MS

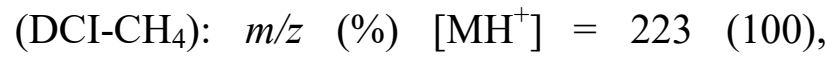
$\left[\mathrm{MC}_{2} \mathrm{H}_{5}^{+}\right]=251(55)$. 1-(trimethylsilyl)-3-[2-(trimethylsilyl)ethynyl] heptadeca-1,4-diyn-3-ol (7). A flame-dried flask was charged under dry argon with a solution of 1-tetradecyne ( $200 \mu \mathrm{L}, 0.81 \mathrm{mmol}, 1$ equiv.) in THF ( $5 \mathrm{~mL})$. To the stirred solution at $0{ }^{\circ} \mathrm{C}$, was slowly added a $1.6 \mathrm{M}$ solution of $n$ BuLi in hexanes $(490 \mu \mathrm{L}, 0.77 \mathrm{mmol}, 0.95$ equiv.). After stirring for $30 \mathrm{~min}$ at the same temperature, a solution of 1,5bis(trimethylsilyl)penta-1,4-diyn-3-one 6 (162 $\mathrm{mg}, 0.73 \mathrm{mmol}, 0.9$ equiv.) in THF ( $1 \mathrm{~mL})$ was added and the mixture was stirred at $-78^{\circ} \mathrm{C}$ for a further $10 \mathrm{~min}$. After treatment with saturated aqueous $\mathrm{NH}_{4} \mathrm{Cl}$ solution, the aqueous layer was extracted with DCM. The combined organic layers were washed with brine, dried over $\mathrm{MgSO}_{4}$ and concentrated under reduced pressure. The crude product was purified by silica gel chromatography (petroleum ether/ethyl acetate, 90/10, $\left.R_{\mathrm{f}}=0.15\right)$ to give 209 $\mathrm{mg}$ of an orange oil assigned to 7 with $69 \%$ yield. ${ }^{1} \mathrm{H}$ NMR $\left(300 \mathrm{MHz}, \mathrm{CDCl}_{3}\right) \delta 2.80$ (s, $1 \mathrm{H}), 2.28(\mathrm{t}, J=7.1 \mathrm{~Hz}, 2 \mathrm{H}), 1.63-1.53(\mathrm{~m}$, 2H), $1.30(\mathrm{~s}, 18 \mathrm{H}), 0.97-0.85(\mathrm{~m}, 3 \mathrm{H}), 0.24(\mathrm{~s}$, 19H). ${ }^{13} \mathrm{C}$ NMR $\left(75 \mathrm{MHz}, \mathrm{CDCl}_{3}\right) \delta(2 \mathrm{C} \equiv \mathrm{C})$

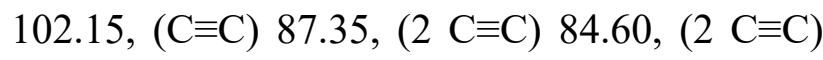
78.11, (C-OH) 54.67, (11 $\left.\mathrm{CH}_{2}\right)$ 31.94, 29.70, 29.67, 29.65, 29.59, 29.38, 29.17, 28.87, 28.05, 22.72, 18.78, $\left(\mathrm{CH}_{3}\right)$ 14.15, (3 C-Si) -0.43; MS $\left(\mathrm{DCI}-\mathrm{CH}_{4}\right): m / z\left[\mathrm{MH}^{+}\right]=417 ; \mathrm{HRMS}$ (DCI$\left.\mathrm{CH}_{4}\right): m / z\left[\mathrm{MH}^{+}\right]$calcd $=417.3009$, found $=$ 417.3008. 
3-ethynylheptadeca-1,4-diyn-3-ol (4). To a solution of the silylated TAC 7 (109 mg, 0.261 mmol, 1equiv.) in methanol $(4 \mathrm{~mL})$ was added $\mathrm{K}_{2} \mathrm{CO}_{3}$ (36 mg, $0.261 \mathrm{mmol}, 1$ equiv.). The solution was stirred for $4 \mathrm{~h}$ at room temperature (completion of the reaction followed on TLC), before treatment with brine. The aqueous layer was extracted with DCM, and the combined organic layers were dried over $\mathrm{MgSO}_{4}$ and concentrated under reduced pressure. The crude product was purified by silica gel chromatography $\left(\mathrm{PE} / \mathrm{Et}_{2} \mathrm{O}, 90 / 10, R_{\mathrm{f}}=0.2\right)$ to give $44 \mathrm{mg}$ of a clear viscous oil product, assigned to 4 with $63 \%$ yield; ${ }^{1} \mathrm{H}$ NMR (300 $\left.\mathrm{MHz}, \mathrm{CDCl}_{3}\right) \delta 2.93(\mathrm{~s}, 1 \mathrm{H}), 2.71(\mathrm{~s}, 2 \mathrm{H}), 2.29$ $(\mathrm{t}, J=7.2 \mathrm{~Hz}, 2 \mathrm{H}), 1.64-1.52(\mathrm{~m}, 2 \mathrm{H}), 1.47-$ $1.23(\mathrm{~m}, 18 \mathrm{H}), 0.90(\mathrm{t}, J=6.75 \mathrm{~Hz}, 3 \mathrm{H}) ;{ }^{13} \mathrm{C}$ NMR $\left(75 \mathrm{MHz}, \mathrm{CDCl}_{3}\right) \delta(\mathrm{C} \equiv \mathrm{C}) 85.31,(\mathrm{C} \equiv \mathrm{C})$ 81.38， $(\mathrm{C} \equiv \mathrm{C}) \quad 77.30, \quad(\mathrm{C} \equiv \mathrm{C}) \quad 71.00, \quad(\mathrm{C}-\mathrm{OH})$ 53.83, $\left(11 \mathrm{CH}_{2}\right)$ 31.94, 29.68, 29.66, 29.62, 29.50, 29.38, 29.09, 28.87, 28.01, 22.72, 18.66, $\left(\mathrm{CH}_{3}\right)$ 14.15; MS (DCI-CH$): m / z\left[\mathrm{MH}^{+}\right]=273$; $\mathrm{HRMS}\left(\mathrm{DCI}-\mathrm{CH}_{4}\right): \quad m / z \quad\left[\mathrm{MH}^{+}\right] \quad$ calcd $=$ 273.2218 , found $=273.2216$.

Nonacosa-13,16-diyn-15-ol (9). A flame-dried flask was charged with a solution of 1tetradecyne (500 $\mu \mathrm{L}, 2.03 \mathrm{mmol}, 1$ equiv.) in THF (15 mL), under dry argon atmosphere. A 1.6 M solution of $n$-BuLi in hexanes $(1.32 \mathrm{~mL}$, 2.24 mmol, 1.1 equiv.) was added slowly at 0 ${ }^{\circ} \mathrm{C}$. The solution was stirred for $30 \mathrm{~min}$ at the same temperature, then a solution of methyl formate (62 $\mu \mathrm{L}, 1.02 \mathrm{mmol}, 0.5$ equiv.) in $\mathrm{THF}$ $(3 \mathrm{~mL})$ was added and the mixture was stirred at $0^{\circ} \mathrm{C}$ for further $30 \mathrm{~min}$. After treatment with a saturated aqueous $\mathrm{NH}_{4} \mathrm{Cl}$ solution and extractions with DCM, the combined organic layers were washed with brine, dried over $\mathrm{MgSO}_{4}$ and concentrated under reduced pressure. The crude product was purified by silica gel chromatography (PE/ethyl acetate, $\left.95 / 05, R_{\mathrm{f}}=0.25\right)$ to give $275 \mathrm{mg}$ of a white solid product, assigned to 9 with $65 \%$ yield. $\mathrm{Mp}=$ $47^{\circ} \mathrm{C} ;{ }^{1} \mathrm{H}$ NMR $\left(300 \mathrm{MHz}, \mathrm{CDCl}_{3}\right) \delta 5.1(\mathrm{~s}, 1 \mathrm{H})$, $2.25(\mathrm{td}, J=7.1,2.1 \mathrm{~Hz}, 4 \mathrm{H}), 2.13(\mathrm{~s}, 1 \mathrm{H}), 1.55$ (q, 4H), 1.42-1.30 (m, 36H), $0.92(\mathrm{t}, J=6.75$ $\mathrm{Hz}, 6 \mathrm{H}) ;{ }^{13} \mathrm{C}$ NMR $\left(75 \mathrm{MHz}, \mathrm{CDCl}_{3}\right) \delta(2 \mathrm{C} \equiv \mathrm{C})$ 85.23，(2 C $\equiv \mathrm{C})$ 78.05, (CH-OH) 52.61, (22 $\left.\mathrm{CH}_{2}\right)$ 31.95, 29.70, 29.67, 29.66, 29.55, 29.39, 29.16, 28.92, 28.41, 22.72, $18.75\left(2 \mathrm{CH}_{3}\right) 14.16$, 14.14; $\mathrm{MS}\left(\mathrm{DCI}-\mathrm{CH}_{4}\right): m / z\left[\mathrm{MH}^{+}\right]=417$, $\left[\mathrm{MC}_{2} \mathrm{H}_{5}^{+}\right]=445$.

Nonacosa-13,16-diyn-15-one (10). To a solution of nonacosa-13,16-diyn-15-ol 9 (104 $\mathrm{mg}, 0.25 \mathrm{mmol}, 1$ equiv.) in DCM (10 mL), was added $\gamma-\mathrm{MnO}_{2}$ (326 mg, $3.75 \mathrm{mmol}, 15$ equiv.) in one portion. The mixture was stirred for $24 \mathrm{~h}$ at room temperature (completion of the reaction monitored by TLC). The mixture was then filtered through a pad of Celite ${ }^{\circledR}$ using DCM and the filtrate was concentrated under reduced pressure. The crude product was purified by silica gel chromatography $\left(\mathrm{PE} / \mathrm{Et}_{2} \mathrm{O}, 85 / 15, R_{\mathrm{f}}=\right.$ $0.5)$ to give $72 \mathrm{mg}$ of a white viscous oil 
product, assigned to $\mathbf{1 0}$ with $70 \%$ yield. ${ }^{1} \mathrm{H}$ NMR $\left(300 \mathrm{MHz}, \mathrm{CDCl}_{3}\right) \delta 2.40(\mathrm{t}, J=7.1 \mathrm{~Hz}$, $4 \mathrm{H}), 1.67-1.55(\mathrm{~m}, 4 \mathrm{H}), 1.29(\mathrm{~d}, J=4.9 \mathrm{~Hz}$, 36H), 0.94-0.85 (m, 6H); ${ }^{13} \mathrm{C}$ NMR $(75 \mathrm{MHz}$, $\left.\mathrm{CDCl}_{3}\right) \delta(\mathrm{C}=\mathrm{O})$ 161.50, $(2 \mathrm{C} \equiv \mathrm{C})$ 94.78, $(2$ $\mathrm{C} \equiv \mathrm{C})$ 82.34，(22 $\left.\mathrm{CH}_{2}\right) \quad 31.94,29.67,29.65$, $29.62,29.46,29.38,29.05,28.90,27.58,22.72$, 19.13, $\left(2 \mathrm{CH}_{3}\right)$ 14.14; IR (neat): $v\left(\mathrm{~cm}^{-1}\right)=3440$, 2965, 2158, 1622, 1255, 1249, 1163, 879, 846, 760; $\mathrm{MS}\left(\mathrm{DCI}-\mathrm{CH}_{4}\right): \mathrm{m} / z(\%)\left[\mathrm{MH}^{+}\right]=415$ (100); HRMS (DCI-CH 4$): m / z\left[\mathrm{MH}^{+}\right]$calcd $=$ 415.3940 , found $=415.3925$.

\section{5-[2-(trimethylsilyl)ethynyl]nonacosa-13,16-}

diyn-15-ol (11). A flame-dried flask was charged with a solution of ethynyltrimethylsilane ( $80 \mu \mathrm{L}, 0.54 \mathrm{mmol}, 1.5$ equiv) in THF $(5 \mathrm{~mL})$ under dry argon atmosphere. A 1.6 M solution of $n$-BuLi in hexanes $(340 \mu \mathrm{L}, 0.54$ mmol, 1.5 equiv.) was slowly added at $-78{ }^{\circ} \mathrm{C}$. After stirring for $30 \mathrm{~min}$ at the same temperature, a solution of nonacosa-13,16-diyn15-one 10 (150 mg, $0.36 \mathrm{mmol}, 1$ equiv.) in THF $(0.5 \mathrm{~mL})$ was added and the mixture stirred at $-78{ }^{\circ} \mathrm{C}$ for a further $10 \mathrm{~min}$. After treatment with $5 \%$ aqueous $\mathrm{NH}_{4} \mathrm{Cl}$ solution and extractions with DCM, the combined organic layers were washed with brine, dried over $\mathrm{MgSO}_{4}$ and concentrated under reduced pressure. The crude product was purified by silica gel chromatography (PE/ethyl acetate, $\left.90 / 10, R_{\mathrm{f}}=0.15\right)$ to give $119 \mathrm{mg}$ a yellow viscous oil product, assigned to 11 with $64 \%$ yield. ${ }^{1} \mathrm{H}$ NMR $\left(300 \mathrm{MHz}, \mathrm{CDCl}_{3}\right) \delta 2.77$ (s, $1 \mathrm{H}), 2.27$ (t, $J=7.2 \mathrm{~Hz}, 4 \mathrm{H}), 1.60-1.55(\mathrm{~m}, 4 \mathrm{H})$, $1.47-1.22(\mathrm{~m}, 36 \mathrm{H}), 0.91(\mathrm{t}, J=6.4,1.9 \mathrm{~Hz}$, $6 \mathrm{H}), 0.23(\mathrm{~s}, 9 \mathrm{H}) \cdot{ }^{13} \mathrm{C}$ NMR $\left(75 \mathrm{MHz}, \mathrm{CDCl}_{3}\right) \delta$ $(\mathrm{C} \equiv \mathrm{C}) \quad 102.82 ，(\mathrm{C} \equiv \mathrm{C}) \quad 86.55 ，(\mathrm{C} \equiv \mathrm{C}) \quad 83.96$, $(\mathrm{C} \equiv \mathrm{C})$ 78.69, $(\mathrm{C}-\mathrm{OH})$ 54.56, $\left(22 \mathrm{CH}_{2}\right)$ 31.95, 29.71, 29.67, 29.67, 29.58, 29.39, 29.17, 28.89, 28.14, 22.72, 18.77, $\left(2 \mathrm{CH}_{3}\right)$ 14.16, 14.14, (3 CSi) -0.36; MS (DCI-CH $\left.)_{4}\right): m / z\left[\mathrm{MH}^{+}\right]=513$; HRMS (DCI-CH$): m / z \quad\left[\mathrm{MH}^{+}\right]$calcd = 513.4492 , found $=513.4481$.

15-ethynylnonacosa-13,16- diyn-15-ol (8). To a solution of the silylated trialkynylcarbinol $\mathbf{1 1}$ (80 mg, $0.16 \mathrm{mmol}, 1$ equiv) in methanol (2 $\mathrm{mL})$ was added $\mathrm{K}_{2} \mathrm{CO}_{3}(20 \mathrm{mg}, 0.16 \mathrm{mmol}, 1$ equiv.). The solution was stirred for $4 \mathrm{~h}$ at room temperature (completion of the reaction followed on TLC) before treatment with brine. The aqueous layer was extracted with DCM, and the combined organic layers were dried over $\mathrm{MgSO}_{4}$ and concentrated under reduced pressure. The crude product was purified by silica gel chromatography $\left(\mathrm{PE} / \mathrm{Et}_{2} \mathrm{O}, 85 / 15, R_{\mathrm{f}}=\right.$ 0.15 ) to give $55 \mathrm{mg}$ of a white viscous oil product, assigned to 8 with $80 \%$ yield. ${ }^{1} \mathrm{H}$ NMR $\left(300 \mathrm{MHz}, \mathrm{CDCl}_{3}\right) \delta 2.77(\mathrm{~s}, 1 \mathrm{H}), 2.66(\mathrm{~s}, 1 \mathrm{H})$, $2.28(\mathrm{t}, J=7.2 \mathrm{~Hz}, 4 \mathrm{H}), 1.66-1.50(\mathrm{~m}, 4 \mathrm{H})$, $1.50-1.21(\mathrm{~m}, 36 \mathrm{H}), 0.97-0.84(\mathrm{~m}, 6 \mathrm{H}) \cdot{ }^{13} \mathrm{C}$ NMR $\left(75 \mathrm{MHz}, \mathrm{CDCl}_{3}\right) \delta(\mathrm{C} \equiv \mathrm{C}) 84.29,(\mathrm{C} \equiv \mathrm{C})$

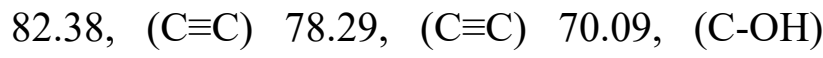
54.16, (22 $\left.\mathrm{CH}_{2}\right)$ 31.95, 29.71, 29.68, 29.65, 29.54, 29.39, 29.13, 28.90, 28.12, 22.72, 18.71, 
$\left(2 \mathrm{CH}_{3}\right)$ 14.15; MS (DCI-CH$): m / z\left[\mathrm{MH}^{+}\right]=$ 441, $\left[\mathrm{MC}_{2} \mathrm{H}_{5}{ }^{+}\right]=469 ;$ HRMS (DCI-CH $\left.{ }_{4}\right): m / z$ $\left[\mathrm{MH}^{+}\right]$calcd $=441.4096$, found $=441.4091$.

\section{Biological evaluations}

MTT tests $(M T T=(3-[4,5-$ diMethylThiazol-2yl]-2,5-diphenyl Tetrazolium bromide). The drugs' cytotoxicity was determined by standard MTT tests on HCT116 cells. In brief, 10.000 HCT116 cells were distributed in 96 flat bottom well plates in 100 microliters of DMEM $10 \%$ FCS and $1 \mu \mathrm{L}$ of DMSO containing the drugs dilutions were then added to each well. For each drug, triplicates of concentrations ranging from $10 \mu \mathrm{M}$ to $5 \mathrm{nM}$ were carried out, by means of 7 successive three fold dilutions of a $1 \mathrm{mM}$ stock solution. Controls always included medium alone, DMSO alone and dilutions of the reference drug $(S)-(+)-1\left(\mathrm{IC}_{50}\right.$ around $\left.0.1 \mu \mathrm{M}\right)$. Plates were then placed in a $\mathrm{CO}_{2}$ tissue culture incubator for $72 \mathrm{~h}$ before the MTT test was performed. This was done by adding $10 \mu \mathrm{L}$ of MTT stock solution $(12 \mu \mathrm{M}, 5 \mathrm{mg} / \mathrm{mL}$ in PBS, Sigma) to each well and incubating the plate for $90 \mathrm{~min}$ at $37^{\circ} \mathrm{C} .100 \mu \mathrm{L}$ of a $0.1 \mathrm{M} \mathrm{HCl}$ aqueous solution in isopropanol ( $\mathrm{v} / \mathrm{v}$ 1/9) were then added to each well, and the plates were returned to $37^{\circ} \mathrm{C}$ for $90 \mathrm{~min}$ before reading the OD absorbed at $570 \mathrm{~nm}$.

Supporting Information. ${ }^{1} \mathrm{H}$ and ${ }^{13} \mathrm{C}$ NMR spectra of the eight compounds 4-11.

\section{Acknowledgements}

M. B. thanks the Tunisian Ministry of Higher Education and Scientific Research for a fellowship. The work was partly performed within the framework of the 'Groupement Franco-Ukrainien en Chimie Moléculaire' (GDRI) funded by the "Centre National de la Recherche Scientifique' (CNRS, France). The authors are grateful to the ukrainian manager of the GDRI, Prof. Zoia Voitenko, Taras Chevtchenko National University in Kiev. D. L. thanks the French Embassy in Kiev for financial support. R. C. is indebted to the CNRS for half of a teaching sabbatical in 2015-2016. Running costs were supported by the Toulouse IDEX Transversalité program 2015 (Fishing Sponge proposal)

\section{References}

[1] Wermuth C., The Practice of Medicinal Chemistry, 3rd Edition, Academic Press; 2008, 982; Patrick G.L., An Introduction to Medicinal Chemistry, Fifth Edition, Oxford University Press, 2013, 816.

[2] For the use of the term "pharmacophore", see: Wermuth CG, Ganellin CR, Lindberg P, Mitscher LA (1998). "Glossary of terms used in medicinal chemistry (IUPAC Recommendations 1998)". Pure and Applied Chemistry. 70 (5): 1129-1143.

[3] Cancer.gov [homepage on the Internet]. Bethesda, MD: NIH National Cancer Institute [updated August 18 2016]. Available from: https://www.cancer.gov/aboutcancer/treatment/drugs

[4] In the anticancer series, the case of the vinorelbine (Navelbine ${ }^{\circledR}$ ) and vinblastine homologues is eloquent: 
Andriamialisoa R. Z., Langlois N., Langlois Y., Potier P. Composés antitumoraux du groupe de la vinblastine: nouvelle méthode de préparation. Tetrahedron 1980; 36: 3053-3060.

[5] Listunov D., Saffon-Merceron N., Joly E., Fabing I., Génisson Y., Maraval V., Chauvin R. Ethynylogation approach in pharmacophore design: from alkynyl- to butadiynyl- carbinols vs antitumoral cytotoxicity. Tetrahedron. 2016; 72: 6697-6704.

[6] For an early coinage of the term "ethynylogation", see: Hafner K.M., Neuenschwander M. Ethynylogous Amides and Urethanes. Angew. Chem. Int. Ed. Engl. 1968; 7: 459-460.

[7] a) Gunasekera S.P., Faircloth G. T. New acetylenic alcohols from the sponge Cribrochalina vasculum. J. Org. Chem. 1990; 55: 6223-6225; b) Aiello A., Fattorusso E., Menna M. Further Bioactive Acetylenic Compounds from the Caribbean Sponge Cribrochalina vasculum. J. Nat. Prod. 1992; 55: 1275-1280; c) Isaacs S., Kashman Y., Loya S., Hizi A., Loya Y. Petrosynol and petrosolic acid, two novel natural inhibitors of the reverse transcriptase of human immunodeficiency virus from petrosia sp. Tetrahedron. 1993; 49: 10435-10438; d) Hallock Y. F., Cardellina J. H., Blaschak M. S., Alexander M. R., Prather T. R., Shoemaker R. H., Boyd M. R. Antitumor Activity and Stereochemistry of Acetylenic Alcohols from the Sponge Cribrochalina vasculum. J. Nat. Prod. 1995; 58: 1801-1807; e) Seo Y., Cho K. W., Rho J. R., Shin J., Sim C. J. Petrocortynes and petrosiacetylenes, novel polyacetylenes from a sponge of the genus Petrosia. Tetrahedron. 1998; 54: 447- 462; f) Shin J., Seo Y., Cho K. W. Five New Polyacetylenes from a Sponge of the Genus Petrosia. J. Nat. Prod. 1998; 61: 1268-1273; g) Kim J. S., Lim Y. J., Im K. S., Jung J. H., Shim C. J., Lee C. O., Hong J., Lee H. Cytotoxic Polyacetylenes from the Marine Sponge Petrosia sp. J. Nat. Prod. 1999; 62: 554-559; h) Watanabe K., Tsuda Y., Yamane Y., Takahashi H., Iguchi K., Naoki H., Fujita T., van Soest R.
W. M. Strongylodiols A, B and C, new cytotoxic acetylenic alcohols isolated from the Okinawan marine sponge of the genus Strongylophora as each enantiomeric mixture with a different ratio. Tetrahedron Lett. 2000; 41: 9271-9276;; i) Nuzzo G., Ciavatta M. L., Villani G., Manzo E., Zanfardino A., Varcamonti M., Gavagnin M. Fulvynes, antimicrobial polyoxygenated acetylenes from the Mediterranean sponge Haliclona fulva. Tetrahedron. 2012; 68: 754-760; j) Legrave N., Hamrouni-Buonomo S., Dufies M., Guérineau V., Vacelet J., Auberger P., Amade P., Mehiri M. Nepheliosyne B, a New Polyacetylenic Acid from the New Caledonian Marine Sponge Niphates sp. Mar. Drugs. 2013; 11: 2282-2292;

[8] a) Gung B. W. Total synthesis of polyyne natural products. C. R Chimie. 2009; 12: 489-505; b) Sui B., Yeh E. A. H., Curran D. P. Assignment of the Structure of Petrocortyne A by Mixture Syntheses of Four Candidate Stereoisomers. J. Org. Chem. 2010; 75: 2942-2954; c) Listunov D., Maraval V., Chauvin R., Génisson Y. Chiral alkynylcarbinols from marine sponges: asymmetric synthesis and biological relevance. Nat. Prod. Report. 2015; 32: 49-75.

[9] a) El Arfaoui D., Listunov D., Fabing I., Oukessou M., Frongia C., Lobjois V., Ausseil F., Ben-Tama A., El Hadrami E. M., Chauvin R., Génisson Y. Identification of chiral alkenyl- and alkynylcarbinols as pharmacophores for potent cytotoxicity. ChemMedChem. 2013; 8:17791786; b) Listunov D., Maraval V., Saffon-Merceron N., Mallet-Ladeira S., Voitenko Z., Volovenko Y., Génisson Y., Chauvin R. On terminal alkynylcarbinols and derivatization thereof. Fr. Ukr. J. Chem. 2015; 3: 21-28; c) Listunov D., Fabing I., Saffon-Merceron N., Gaspard H., Volovenko Y., Maraval V., Chauvin R., Génisson Y. Asymmetric synthesis and biological evaluation of natural or bio-inspired cytotoxic $\mathrm{C}_{2}$-symmetrical lipids with two terminal chiral alkynylcarbinol pharmacophores. J. Org. Chem. 2015; 80: 5386-5394; d) Listunov D., Billot C., Joly E., Fabing I., Volovenko Y., Génisson Y., Maraval 
V., Chauvin R. Extended structural modulation of bioinspired chiral lipidic alkynylcarbinols as antitumor pharmacophores. Tetrahedron. 2015; 71: 7920-7930; e) Listunov D., Mazères S., Volovenko Y., Joly E., Génisson Y., Maraval V., Chauvin R. Fluorophore-tagged pharmacophores for antitumor cytotoxicity: modified chiral lipidic dialkynylcarbinols for cell imaging. Bioorg. Med. Chem. Lett.. 2015; 25: 4652-4656.

[10] For the compounds 5 and 6 see: Detty M. R., Luss H. R. Addition of disodium chalcogenides to 1,5bis(trimethylsilyl)penta-1,4-diyn-3-one. Syntheses, structure, and reactivity of the parent $\Delta-4 H$ chalcogenapyran-4-ones. Organometallics 1992; 11: 2157-2162.

[11] Tedeschi C., Saccavini C., Maurette L., Soleilhavoup M., Chauvin R. 1,4-diynes from alkynyl-propargyl coupling reactions. J. Organomet. Chem. 2003; 670: 151169.

[12] Tropsha A. Best Practices for QSAR Model Development, Validation, and Exploitation. Molecular Informatics 2010; 29: 476-488. 